\title{
An Analysis on Factors That Contributed to the Popularity of the Hungary Right-Wing Populist Fidesz Party between the Years 2008-2020
}

\author{
Qirui $\mathrm{Li}^{1, \dagger}$, Xiongzheng Teng ${ }^{2, *, \dagger}$, Tianhao Yuan ${ }^{3, \dagger}$ \\ ${ }^{1}$ Valley Christian School, San Jose CA, 9511, USA \\ ${ }^{2}$ Shanghai American School Pudong, Shanghai, 201201, China \\ ${ }^{3}$ Guangdong Experimental High School, Canton, 510000, China

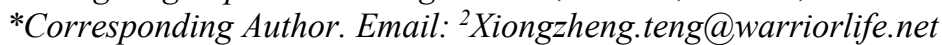 \\ ${ }^{\top}$ Those authors contributed equally.
}

\begin{abstract}
The Fidesz party, which is known as a right-wing populist party, has gained control in Hungary, and keep running the country to today since they won most of seats in Hungarian parliamentary election in 2010. This article reviews the rise of the Fidesz party in Hungary between the years 2008 and 2020, discusses the reasons why it can rise from different aspects. First, the utilization of rhetoric in consolidating power for the Fidesz party is discussed. To unite citizens and distract their attention, the Fidesz party invokes that there are powerful threats to the nation, just like other right-wing populist party. Then, the attitude which the Fidesz party toward the asylum seeker immigration is elucidated. Since the start of the European Refugee Crisis in 2015, the Fidesz party has expressed the country's lack of tolerance for asylum seekers, just like other right-wing populist party. At last, the economic policy which the Fidesz party carry out is discussed in this paper. The economic policies of the party stress upon demonstrating its populist agenda. As a conclusion, this paper finds that: the Fidesz party uses three methods to rise and strengthen their position in Hungary politics: It changed Hungary economic from negative growth to positive by levying special taxes on banks and multinational companies to nationalize private pensions, satisfying the common people, and expelling foreign control. In asylum seeker immigration problem, a strong resistance measures have been taken, which is contrary to mainstream European countries, and it was supported by Hungarian people. At last, the rhetoric utilized by the Fidesz party creates ideologies that favor the Fidesz party, through created a conception of "threats", to consolidate its stable position in politics.
\end{abstract}

Keywords: Hungary, Fidesz party, Orbán government.

\section{INTRODUCTION}

From Donald Trump to Jair Bolsonaro, populist leaders have gained great prominence in Western Democratic states. One of the most notable cases is the rise of the Hungarian Civic Alliance, also known as the Fidesz party, and its leader Viktor Orbán. As of currently, Orbán has served as the prime minister of Hungary for three consecutive terms ever since his initial instatement in 2010, becoming the country's longest-serving prime minister. To understand how immigration impacted the propagation of populism in Hungary, the concept of populism must be defined. Populism is the idea that politics should be utilized to suit the interests of the common people, rather than the elite. Populist leaders, in theory, should represent and satisfy the will of the common people. In practice, populism presents itself in different ways across various geographical and historical contexts. More recently, populist leaders in the West are understood to be charismatic individuals who often appeal to nationalist sentiments and other right-wing political views. These leaders emphasize the fears of the states' populous and construct common threats or goals for the entirety of the country. Given that Orbán and his government are undoubtedly conservative and actively stresses the Hungary identity concerning conservative values, the Orbán administration should be considered a populist government. 
Populism often appears to be a reaction to external groups such as asylum seekers. However, the environment that leads to the instatement of populist governments is complex and multifaceted meaning that a single factor cannot be the sole reason. The instatement of populist governments always involves a combination of social, economic, and political circumstances. Understanding such, this paper seeks to explore how important of a factor is asylum seeker immigration in the continual support of the Fidesz party. Through such, a greater understanding of the rise of right-wing populism in the West can be developed, exposing the core components of the support for this potentially dangerous political system. By understanding the rise of populism in the West and the relationship between the major stakeholders in this case study, which are the immigrants, the Hungarian populous, and the political parties of Hungary, one can identify the phenomenon's root causes and potentially develop ideas to deter its growth.

The research question will be primarily analyzed through the theories of constructivism and marxism. Constructivism is particularly integral to the exploration of this topic as nationalism, a common element of populism is a matter of great concern to constructivist theorists. The constructivist notion of nationalism outlines that the nation is an imagined concept constructed by those in power rather than preexisting characteristics. Seeing that "the Hungarian identity" is a matter of great concern to the Orbán administration and its supporters, constructivism naturally assumes a crucial role in analyzing the topic. Additionally, constructivism emphasizes the importance of non-state actors in international relations and explores the relationship between non-state actors and state actors. As populism is a political movement that emphasizes the representation of the common people, the non-state actor of the Hungarian people cannot be separated from the analysis of this topic.

\section{THE UTILIZATION OF RHETORIC IN CONSOLIDATING POWER FOR THE FIDESZ PARTY}

As a right-wing populist and national-conservative political party, there are many similarities between the Fidesz party and other right-wing populist party. They anti-communism, anti-culture diversity, nativism, were accused of antisemitism, and adopted anti-immigration stances and rhetoric. They also have many conflicts with the European Union in many aspects, like the reintroduction of the death penalty and the European migrant crisis. Although Hungary had a period which ruling by left-wing party with more advanced policies, and the policies which they promulgated recently usually be treated as the opposite of the pan-European values, the Fidesz party actually has many supports of
Hungarians. In the 2010, the Fidesz party won 227 seats out of a total of 386 seats in Hungarian parliamentary election, becoming the largest party in Hungary. Since 2002, after 8 years, the Fidesz party was elected as the ruling party again. It won a total of 263 seats and a twothirds majority of seats in Parliament with its ally, the Christian Democratic People's Party. It is an interesting phenomenon, seems like the Fidesz government rewrite sovereignty, and actually, they did, through many ways. For example, the utilization of rhetoric.

To unite citizens and distract their attention, the right-wing populist party like the Fidesz party always invoke that there are powerful threats to the nation. Those "threats" can be divided as two parts: the internal threats and the external threats. Populist governments often obliquely refer to classes of citizens or residents of the state as threats to the nation [1]. In most cases, ethnic minorities would be played this role. Jews is a good example, they have played this tragedy role many times in history, like the Holocaust during the Second World War. As I earlier mentioned, antisemitism is one of the characteristics of the Fidesz party, so in contemporary Hungary, Jews play this role once again. In 2014 , on the $70^{\text {th }}$ anniversary of the Nazi occupation of Hungary, the erected of controversial monument "German occupation monument" downplays Hungary's role in extermination of Jews during World War II. As responded, Orbán, the leader of the Fidesz party said that it was not a Holocaust memorial, but instead marked [Hungary's] "loss of state sovereignty" [2].

Seemingly, the populist governments are most fond of invoking powerful external threats to the nation [1]. For example, once in a speech, Orbán distanced himself from the former socialist government, said that "We will not be a colony" and "Hungarians will not live as foreigners dictate it, will not give up their independence or their freedom" [3]. Because of the negative memory of the period which Hungary was pressured by the Soviet Union, most of Hungarian do not have good impressive of the communism, which usually be treated as the symbolic of the left-wing party. So many people prefer the party which opposite the previous party, believe their speech. Also, because of the mistakes which made by previous government, and the citizen's negative impression to the previous government, present government has the confidence to arrested people who have links with the foreign donors and states. Like what Orbán had said: "We're not dealing with civil society members but paid political activities who are trying to help foreign interest here." "It's good that a parliamentary committee has been set up to monitor the influence of foreign monitors" [4].

\section{HUNGARY AND ASYLUM SEEKER IMMIGRATION}

Since the start of the European Refugee Crisis in 
2015, Orbán has expressed the country's lack of tolerance for asylum seekers. Orbán claimed that Europe was "in the grip of madness over immigration and refugees". He stated that most of the migrants "are not Christians, but Muslims" and this is problematic because "Europe and European identity is rooted in Christianity". To protect the Christian identity of Hungary, the country has "no option but to defend [its] borders" [5]. Compared to Western European states, Hungary adopted a far more intolerant approach to refugee immigration. In 2015, Orbán ordered the construction of a barbed-wire fence along the Hungarian-Serbian border to deter more asylum seekers from entering the country. Furthermore, the country rejected the calls for mandatory quotas for sharing migrant settlement in the European Union, with Orbán stating in 2016 that Hungary will "ever, never, ever accept the mandatory quota for migrants" [6]. While more than 177,135 asylum seekers entered the country in 2015, only 6 of them attained the status of tolerated stay. Despite these sentiments and policies, more than 12,000 nationals that settled illegally from third-world countries were found in the country. Such policies did not become more lenient throughout the years. The Fidesz government continues to run on a strong antiasylum seeker immigration platform. In 2020, Orbán vetoed a $\$ 2.26$ trillion budget and recovery package for the EU as he deemed the package to be a threat to the zero-tolerance stance of Hungary. In the same year, the Court of Justice of the European Union ruled that Hungary's practices of denying migrants and refugees a right to apply for asylum and forcibly deporting them to the Serbian border are acts that violate EU law. Additionally, the Hungarian Helsinki Committee, a nongovernmental organization that provides assistance to refugees, noted that an increase of status withdrawals occurred in 2020 due to vaguely defined "national security reasons" [7]. The accumulation of these policies has led to the forceful removal of more than 71, 000 people between the years 2016-2021. Such aggressive policies not only garnered condemnation from European bodies but the United Nations as well. The actions of the Orbán administration have been continuously deplored by the United Nations Refugee Agency, urging in 2021 for the Hungarian government to "withdraw these legislative provisions and ensure that people who wish to seek international protection, many of whom are fleeing war, violence, and persecution, have effective access to its territory and to the asylum procedure" [8]. Evidently, the Hungarian approach to addressing asylum seekers is one that is scorned upon by many other states, intergovernmental bodies, and nongovernmental organizations.

Such radical policies that stray away from the will of many closely associated states must be an issue of great concern to the Hungarian public. With such heavy external pressure for the Orbán administration to forfeit its hardline attitude towards asylum seeker immigration, significant domestic support must be needed. A study conducted in 2016 revealed that Hungarians generally hold less tolerant views when it comes to asylum seekers. According to a Pew Research Center survey, more than $82 \%$ of Hungarians believe "refugees are a burden" that take away jobs and social benefits, more than $76 \%$ believe "refugees will increase the likelihood of terrorism" in the country, and more than $69 \%$ believe "large numbers of refugees leaving Syria/Iraq" pose a major threat to the country. The EU median percentage for each of these attitudes are 50\%, 59\%, and 49\% respectively. Furthermore, Hungarians are more likely to hold negative views of other ethnic or religious groups. $72 \%$ of Hungarians hold unfavorable views for Muslims, 64\% for Roma (Gypsies), and 32\% for Jews. In comparison, the respective EU medians are $43 \%$, $48 \%$, and $16 \%$. It would therefore be reasonable to assume that the policies of Orbán are quite popular. In fact, more than $71 \%$ of Hungarians approve of Orbán's response to the Refugee Crisis [9]. Similar attitudes toward refugees appear to maintain in the Hungarian public, as $63 \%$ of Hungarians still view illegal immigration to the country as a concerning issue as of March 2020. In comparison, only 53\% of Hungarians view the spread of the Coronavirus as a pressing issue. Undoubtedly, asylum seeker immigration is still a matter of great concern to many Hungarians. The approval for Orbán policies is reflected through the rise in popularity for the Fidesz party during the same timeframe. This can be seen by the fact that the Fidesz party got voted into parliament for a third consecutive term in 2018, with support rates for the party nearing $40 \%$ by 2018 , a rate that reached a seven-year high [10]. Furthermore, starting from the beginning of the Refugee Crisis in 2015, the national voting intention for the Fidesz party increased from $43 \%$ to $50 \%$ by the start of 2020 [10]. Statistically, the populist party of the Fidesz in Hungary did benefit greatly from the illiberal asylum seeker policies imposed in the country.

\section{ECONOMIC RECESSION AND "ORBANOMICS"}

The Fidesz party came into power in 2010, about five years before the refugee crisis. The party got reelected once in 2014 before its second reelection in 2018. Therefore, there must be other factors in place to ensure the initial popularity of the Fidesz government and its reelection. Furthermore, since populism is often a consequence of a variety of complex factors, there must be other policies aside from the presence of asylum seekers that contributed to the continual popularity of the Fidesz party.

One of the major issues plaguing Hungary before Fidesz's initial claim to a majority in parliament was the economic crisis the state suffered under The Hungarian 
Socialist Party. Between the years 2006-2010, economic growth has stagnated. The economy mainly grew through faster capital accumulation and the increasing number of hours worked. However, projections showed that the two ways will eventually become ineffective in generating economic growth as the margins of convergence through them will eventually be exhausted. Due to the global financial crisis of 2008, the county's large amount of external debt and expansive fiscal policy became an unmanageable burden for the government. Suffering from both a large external debt and governmental debt, households and firms suffered the impacts of a large buildup of unhedged foreign liability positions in their balance sheets. The liabilities were mostly of Swiss franc and less so the euro. Thus, the value of the Hungarian currency depreciated by $66 \%$ against the Swiss franc and by $26 \%$ relative to September 2008 by November of 2011[11]. The general economic downturn of the country became more apparent after 2008 as unemployment rates rose from $7.41 \%$ in 2007 to $11.17 \%$ in 2010 [12]. By the end of 2011, the Hungarian government requested assistance from the International Monetary Fund and escaped the crisis.

After Orbán took office, many radical economic policies were adopted. Holding the idea that foreign capital dominated the interests of the Hungarian economy, Orbán sought to restore control over major sectors into Hungarian hands. Through the implementation of a mega-tax, large investors were discouraged to further conduct their operations in the country and progressively left, allowing for domestic firms to fill in their places. Furthermore, the government has taken extensive measures to fulfill other economic needs. Expansive social programs had been established with the intent to support families. Many public works programs were implemented, including the building of the barbed walls on the Serbian border, increasing employment [13]. To further encourage employment, the administration lowered income taxes and reduced social benefits.

Since the instatement of the Fidesz party, the growth rate of the Hungarian economy has been rather unstable. The highest GDP growth rate occurred in 2018 , being $5.4 \%$. The lowest growth rate aside from 2020, the year of the pandemic where most economies suffered greatly, is in 2012, with the rate being $-1.381 \%$ [14]. Aside from the two years, Hungary enjoyed a positive growth rate between the years 2010 and 2020. However, the growth rate does not follow a linear pattern of a continual increase. Despite the inconsistencies in the GDP growth rate, the Hungarian government had satisfied other macroeconomic goals. Between 2013 and 2020, the inflation rate of Hungary has stayed somewhere 2-4\% [15]. As the worldwide average inflation rate for developed countries such as Hungary is around 2\% [16], the Fidesz government has maintained a healthy inflation rate. Additionally, unemployment levels have steadily fallen from $11.17 \%$ in 2010 to $3.42 \%$ in 2019 , rising only to $4.35 \%$ in the pandemic year. Therefore, looking at the statistics, the government was to be able to reinvigorate the Hungarian economy after receiving external support from the IMF. There are many critics of the Hungarian model of growth. Their most prominent point is that the heavy amount of government involvement in the economy creates a business environment where people are disincentivized to invest or engage in entrepreneurship [17]. However, such a concern has not manifested to damage the Hungarian economy greatly.

By bringing stability and growth to the Hungarian economy, the Fidesz party grows its internal legitimacy. The populous naturally want their governments to be ones that can bring prosperity to society; oftentimes, such prosperity translates to economic wellbeing. By facilitating the recovery, growth, and stability of the economy, the Fidesz party can garner support from the people. Coupled with the previously mentioned approval ratings of the party, it becomes apparent that the Fidesz party's popularity comes not only from its attitude towards refugees but also from its economic policies. The economic policies of the party stress upon satisfying the common people and expelling foreign control, once again demonstrating its populist agenda. The model of development that Hungary adheres to betrays the neoliberal idea that development can be best achieved through international market deregulation and free trade. Such a contradiction serves to satisfy the needs of the people. Thus, the constructivist idea that non-state actors, in this case being the Hungarian people, hold equal significance as state actors is buttressed.

\section{CONCLUSION}

\subsection{Nationalism Economic policy wins over the people}

The international financial crisis in 2008 not only severely damaged the global economy, but also further aggravated the economic gap within developed countries and the sense of deprivation of the silent majority. The economic consequences of globalization are the expansion of capital and the decline of the labor force. Although Hungary is a beneficiary of globalization, it has not solved the imbalance between domestic capital and labor relations, and the conflict between multinational companies and domestic companies. However, Hungary's economy has changed from negative growth to positive, with the "unorthodox" economic measures taken by the Orban government, such as levying special taxes on banks and multinational companies to nationalize private pensions, satisfying the common people, and expelling foreign control. There is 
a tendency for the government to adopt economic nationalism policies to protect the interests of its own people, which is conducive to the trend of globalization. The government was to be able to reinvigorate the Hungarian economy after receiving external support from the IMF. There are many critics of the Hungarian model of growth. Their most prominent point is that the heavy amount of government involvement in the economy creates a business environment where people are disincentivized to invest or engage in entrepreneurship. Since the reinstatement of the Fidesz party, the growth rate of the Hungarian economy has been rather unstable, and the growth rate does not follow a linear pattern of a continual increase. However, such a concern has not manifested to damage the Hungarian economy greatly by reviewing the statistical inflation rate, GDP growth rate, and unemployment rate.

\subsection{Asylum Seeker Immigration's Contribution to the Popularity of the Fidesz Party}

The relationship between the government and the Hungarian populous reflects constructivist dynamics between state actors and non-state actors. The choice for the Hungarian government to reject the requests of other European states and intergovernmental bodies to be more tolerant of refugees rejects the liberal notion of collective benefits. Liberalism emphasizes the role of international bodies in ensuring that multiple states can benefit from multilateral agreements in this case being the budget and recovery package. In an act that pushes the burdens of facilitating the settlement of asylum seekers to other states while also undermining economic benefits, Hungary itself may receive. However, Hungary's actions also defy realist theories. Western European states such as Germany and France hold more hard and soft power than Hungary, being more militarily and economically developed while enjoying greater international presence. Hungary's refusal to conform to their demands demonstrates a betrayal of the hegemonic view of power, where weaker states naturally gravitate to serve the interest of more powerful states. Furthermore, Hungary's refusal to comply with these states and the EU potentially jeopardizes the benefits the country enjoys from trade, economic deregulation, and direct support. Thus, Hungary's actions serve to undermine the country's ability to maintain survival as the state becomes comparatively weaker. Meanwhile, constructivism rejects the rigid notions of both liberalism and realism, providing a logical framework to analyze the case of Hungary. The opposition to the entry of asylum seekers represents an ideational factor. Understanding that Hungary is a democratic country that hosts elections, the influence and power of the Fidesz party depend on the vote of Hungary's people. Furthermore, the populist system's purpose is to attain political power by appealing to the will of the people. Therefore, the instatement of the populist government adheres to constructivist theory on an ideological and systemic level. The popularity of the Orbán administration is in part due to the appeal of its staunch policies against asylum seekers. This can be seen through the statistics relating to public opinion and the approval ratings of the party. The attitudes the Hungarian populous hold against refugees and peoples of other ethnicities and religions represent the norms of Hungarian society. The Christian identity of Hungary stressed by Orbán also represents another norm. These norms dictated Hungary's implementation of hardline policies against asylum seekers. Noting the potent responses of various foreign actors to Hungary's policies, the issue assumes great importance in international relations. Thus, just as constructivists would suggest, the norms of Hungary hold great significance in a global context. Considering the fact that the Fidesz party rose in popularity after implementing harsh policies against asylum-seeker immigration, thereby adhering to the will of the people, asylum seeker immigration contributed greatly to the continual support of populist governments in Hungary.

\subsection{The rhetoric utilized by Viktor Orbán creates ideologies that favor the Fidesz party}

In the main body paragraph, this paper has shown a general understanding on how the Fidesz party utilize rhetoric to control the direction of public opinion, create a public opinion environment which is beneficial to them. To unite citizens and distract their attention from the main conflict of the country, they propagate that there are "internal threats" and "external threats" that threaten the live and safety of the country and its citizens. We can see that the "internal threats" and "external threats" actually serve a same purpose-to consolidate the stable of the Fidesz party. So, to better understanding, we can compare the populist government which control by the Fidesz party, a right-wing populist and national-conservative political party with its competitor, the non-populist government which control by the left-wing socialists, and the differences between Orbán's speech which announced before he got the power and after his party won in Hungarian parliamentary election. Therefore, we would find out their difference, and have a better understanding on how Viktor Orbán, the leader of the Fidesz party, utilized rhetoric to creates ideologies that favor the populist government.

Because of the differences between left-wing nonpopulist party and right-wing populist party, Orbán utilizes the differences between two parties to demonstrate his party and shows harder work on it. For example, the Fidesz party claimed that the left-wing party represent a "leftist revolutionary past", and 
contrast them with the 1848 and 1956 revolutions, which are the sad time memories for Hungarians, to claim that the leftist force is "evil and treachery" (the internal threats) [18]. And as this paper previous mentioned in former paragraph, the Fidesz party would use policy to prevent this situation happen. As compare, the propaganda of left-wing party has been more likely to give relatively ordinary speeches which more focused on the events themselves. For example, Gyurcsány, the leader of the socialist party, in his 2009 speech commemorating March 15 follows said that: "the country has become free and independent; a member of the world's strongest military and political alliance; an equal member of the European Community," and claimed that these was what the 1848 revolutionaries had sought to achieve [18]. Compare two parties, we can see that the Fidesz party would give clear goals and enemies to citizens and use practical action to deal with those "problems", which have a good impression to citizens that this party is actually enhancing country, cares about this country people. The Fidesz party also evokes the bad memories to the left-wing party, which gave a huge impact to the left-wing party. The left-wing party did not have good methods to deal with it, and their propaganda which is not clear enough also give a worse impression to citizens.

In order to make the negative impressions of leftwing party more popular, the Fidesz party also claimed that the left-wing party have tie to Russia, the external threat. In Orbán's October 23, 2007 speech, he declared that 1956 was "a revolution against the east", proclaiming that: "Eastern politics does not allow for freedom, independence, and sovereignty. It abolishes the lines of defense of the independent life of the people. It makes us poor, vulnerable; intimidates us. Our life becomes parts in the chain dependent on the powerful." [18] However, after he is seizing the power in 2010, he decreased the significance on the role of Russia, instead of the importance of maintaining Hungarian sovereignty and creating their own future: "Freedom does not only mean that the Soviets are not here, and we are not prisoners of Comecon. Freedom does not only mean that twe liberate and take back our own country. Freedom does not end here; it only starts here. Freedom meansas Attila József taught - that we can liberate, and we should liberate our own lives." [1]8 From the change of the attitude to Russia, we can see that the "threats" just a target which give the Fidesz party a chance to benefit themselves. When the "threats" could give them advantages, the "threats" are no longer a enemy to them, instead of a friend, and they just set up another target to distract the attention of citizens from what just happen previously.

After all, the "threats" actually not that important to Orbán and his Fidesz party. It just their utilization of rhetoric to consolidate its stable position in politics.

\section{REFERENCES}

[1] Erin K. Jenne, How populist governments rewrite sovereignty and why. (n.d.). Retrieved October 19, 2021, from https://www.ceu.edu/sites/default/files/attachment/e vent/15587/erinjennepolberg-consec-2016.pdf.

[2] Sam Sokol, "German Occupation Statue in Budapest not a Holocaust Memorial, Orban Says," The Jerusalem Post, June 11, 2014, http://www.jpost.com/Jewish-World/JewishFeatures/German-occupation-statue-in- Budapestnot-a-Holocaust-memorial-says-Orban-355939

[3] Ian Traynor, "Hungary prime Minister Hits Out at EU Interference in National Day Speak," The Guardian, 15 March 2012.

[4] Zoltan Simon, "Orban says He Seeks to End Liberal Democracy in Hungary," Bloomberg News, July 14, 2014.

[5] I. Traynor, Migration crisis: Hungary PM says Europe in grip of madness, Guardian, 2015-09-13, Migration.

[6] Viktor Orbán, Encyclopedia Britannica, 2021-0702, Prime Ministers.

[7] AIDA 2020 Update: Hungary, European Council on Refugees and Exiles, 2021-04-16, ECRE Weekly Bulletin.

[8] UNHCR Concerned by Hungary's Latest Measures Affecting Access to Asylum, United Nations High Commissioner for Refugees, 2021-03-10, Press Releases.

[9] M. Dorothy, Hungarians Share Europe's Embrace of Democratic Principles but Are Less Tolerant of Refugees, Minorities, Pew Research Center, 201609-30, International Political Values.

[10] Approval Rating of Hungarys Ruling Fidesz Party at 7-Year High, Portfolio, 2018-02-09, Economy

[11] Valentinyi, Akos. "The Hungarian Crisis." VOX, CEPR Policy Portal, 19 Mar. 2012, voxeu.org/article/hungarian-crisis.

[12] Statista. "Opinion of Hungarians on Coronavirus, Climate Change, and Illegal Immigration 2020." Statista, $\quad 19$ Mar. 2020, www.statista.com/statistics/1103129/hungary-mostconcerning-issues.

[13] Tacconi, Matteo. “'Orbanomics' or Why Hungary Needs Europe." Reset DOC, 28 Nov. 2018, www.resetdoc.org/story/orbanomics-hungaryneeds-europe.

[14] "GDP Growth (Annual \%) - Hungary | Data." The 
World

Bank,

data.worldbank.org/indicator/NY.GDP.MKTP.KD.

ZG?locations $=$ HU. .

[15] "Installment Report: POLITICO Poll of Polls Hungarian Polls, Trends and Election News for Hungary." POLITICO, www.politico.eu/europepoll-of-polls/hungary.

[16] Cameron, Steffani. "What Is a High Rate of Inflation?" Bizfluent, 27 Sept. 2019, bizfluent.com/about-7518068-high-rateinflation.html.

[17] Piasecki, Marcin. (2015). Was Viktor Orbán's Unorthodox Economic Policy the Right Answer to Hungary's Economic Misfortunes?. International Journal of Management and Economics. 46. 10.1515/ijme-2015-0021.

[18] Erin K. Jenne, How populist governments rewrite sovereignty and why. (n.d.). Retrieved October 19, 2021, from https://www.ceu.edu/sites/default/files/attachment/e vent/15587/erinjennepolberg-consec-2016.pdf. 